\title{
ANALISIS PERKEMBANGAN SUMBERDAYA LAHAN PERTANIAN DAN KETAHANAN PANGAN DI PROVINSI DAERAH ISTIMEWA YOGYAKARTA
}

\author{
SITI SYAMSIAR \\ Staf Pengajar Jurusan Sosial Ekonomi Pertanian, Fakultas Pertanian, UPNVY
}

\begin{abstract}
The one of development strategy and established of food security in Daerah Istimewa Yogyakarta (DIY) is using food production capacity development that related with optimize of the using of land resources. This effort has a opportunity to success remind that land resources in D I Y has wet land as wide as 57.661 hectare and dry land as wide as 260.919 hectare, also un use shore land that can be use for agriculture activities. There are many scenarios for to development these, such as 1) wet land and dry land intensification, and rising productivity acceleration of non optimal irrigated wet land, 2) extensification of shore land. Implementation of these scenarios needed supporting to solve technical and non technical problems, like controlling of agriculture land convertion, the wide of agriculture land that tend to limited. As a whole, the handling of land resources need synergy cooperation inter sector in developing and needed political will from D I Y goverment in filling food sufficient trough increasing of food production in D I Y.
\end{abstract}

Key words : development, land resources, food security.

\section{PENDAHULUAN}

Sumberdaya lahan merupakan sumberdaya alam yang sangat penting untuk kelangsungan hidup manusia karena sumberdaya lahan merupakan masukan yang diperlukan untuk setiap aktivitas manusia seperti untuk pertanian, industri, permukiman, pariwisata, perdagangan dan jasa (Suparmoko, 2000). Pemanfaatan sumberdaya lahan untuk berbagai penggunaan bertujuan untuk menghasilkan barang - barang pemuas kebutuhan manusia yang terus meningkat karena jumlah penduduk yang terus bertambah dan perekonomian yang semakin berkembang.

Penggunaan lahan pada umumnya tergantung pada kemampuan lahan dan lokasi. Untuk aktivitas pertanian, penggunaan lahan tergantung pada kelas kemampuan lahan yang dicirikan oleh sifat-sifat seperti tekstur tanah, kemampuan menahan air, kelerengan, tingkat erosi yang terjadi. Penggunaan lahan yang paling luas adalah untuk sektor pertanian, baik berupa lahan basah yaitu sawah atau lahan kering seperti tegalan yang dimanfaatkan oleh manusia untuk memenuhi kebutuhannya yang salah satunya merupakan kebutuhan pokok yaitu pangan. Sumberdaya lahan pada kajian ini difokuskan pada lahan yang dapat dipergunakan untuk pertanian ,baik berupa lahan sawah, lahan bukan sawah seperti tegalan dan lahan pasir pantai selatan D I Y.

Ketahanan pangan dalam UndangUndang No 7 Tahun 1996 Tentang Pangan diartikan sebagai: " Kondisi terpenuhinya kebutuhan pangan setiap rumahtangga yang tercermin dari tersedianya pangan yang cukup, baik jumlah maupun mutunya aman, merata dan terjangkau ". Hal ini menyangkut aspek makro, yaitu tersedianya pangan yang cukup, sekaligus aspek mikro, yaitu setiap rumah tangga dapat menjangkau pangan untuk menjalani hidup sehat dan aktif. Untuk mencapai kondisi ideal tersebut, menurut Suryana (2004), strategi yang dikembangkan adalah : 1) pengembangan kapasitas produksi pangan, 2) pengembangan pasar, 3) peningkatan keberdayaan dan partisipasi masyarakat, 4) pengembangan dan peningkatan intensitas jaringan kerjasama lintas pelaku, lintas wilayah, dan lintas waktu, 5) peningkatan efektifitas dan kualitas kinerja pemerintah, 6) pengembangan agribisnis pangan yang berdaya saing, berkerakyatan, berkelanjutan, dan terdesentralisasi.

Perkembangan jumlah penduduk di D I Y yang terus bertambah setiap tahun sebesar 0,89 $\%$ atau sebesar 27.748 jiwa/tahun (Bapeda DIY,2007), membutuhkan tambahan produksi pangan khususnya padi sebanyak 2.359 ton/tahun gabah kering giling atau setara dengan $1.486,17$ ton beras untuk konsumsi penduduk di DIY. Produksi padi di DIY tahun 2006 sebesar 708.183 ton gabah kering giling atau setara dengan 446.143 ton beras menggunakan pendekatan besaran rendemen $63 \%$ (Dinas Pertanian DIY, 2007). Bila konsumsi beras per kapita $100 \mathrm{~kg} /$ tahun maka penduduk di DIY 
sebesar 3.315.552 jiwa membutuhkan 331.555,2 ton beras per tahun. Secara agregat sampai dengan tahun 2006 terdapat surplus beras di DIY sebesar $114.587,8$ ton.

Bila jumlah penduduk di DIY terus bertambah sedangkan jumlah produksi beras tidak bertambah maka sampai disuatu saat jumlah produksi akan tidak mencukupi kebutuhan beras penduduk di DIY. Tulisan ini dilakukan untuk mengidentifikasi kapan produksi beras tidak mencukupi konsumsi beras di DIY, dan penurunan lahan sawah serta peluang peningkatan produksi pangan (beras).

Untuk kajian ini fokus bahasan adalah strategi yang pertama yaitu pengembangan kapasitas produksi pangan khususnya padi, melalui pendayagunaan sumberdaya lahan dalam rangka mendukung ketahanan pangan dilihat dari aspek penyediaan pangan yang cukup bagi penduduk di DIY.

\section{METODOLOGI PENELITIAN}

Untuk mengakselerasi peningkatan produksi pangan khususnya padi di D I Y maka sumberdaya lahan dianalisis kecenderungan pemanfaatannya ke depan. Metode pendekatan, asumsi dan strategi yang dilakukan melalui, 1) perhitungan potensi dan proyeksi, 2) skenario peningkatan produksi.

\section{Perhitungan potensi dan proyeksi}

Perhitungan potensi sumberdaya lahan dilakukan berdasarkan analisis data penggunaan lahan sawah dan bukan sawah, untuk diprediksi perkembangannya ke depan melalui peningkatan frekuensi tanam. Digunakan data tabulasi dari Dinas Pertanian Provinsi D I Y mulai tahun $2002-2006$.

Perhitungan proyeksi kebutuhan pangan, didasarkan atas data proyeksi produksi, dan konsumsi serta gap yang terjadi sehingga dapat diprediksi kapan DIY tidak tercukupi pangannya dan strategi apa yang dilakukan agar kemandirian pangan tetap terjaga, dalam rangka mendukung ketahanan pangan di DIY.

\section{Skenario peningkatan produksi}

Skenario 1. Intensifikasi, melalui peningkatan Indeks Penanaman pada lahan sawah dengan frekuensi tanam dua kali dan lahan tegalan atau bukan sawah tanam satu kali. Asumsi produktivitas padi sawah dalam bentuk beras 4 ton/hektar, padi lahan tegalan bukan sawah 2,3 ton/hektar. Skenario 2. Ekstensifikasi, pada lahan pasir pantai. Sumberdaya lahan pasir pantai dapat dimanfaatkan untuk mendukung ketahanan pangan dengan frekuensi tanam padi satu kali. Asumsi produktivitas lahan dalam bentuk beras 2 ton/hektar.

\section{HASIL DAN PEMBAHASAN}

\section{Ketersediaan Sumberdaya Lahan}

Ketersediaan Sumberdaya lahan berupa lahan sawah dan lahan bukan sawah yaitu lahan kering seperti tegalan di D I Y dari tahun 2002 sampai 2006 dapat dilihat pada Tabel 1.

Tabel 1. Ketersediaan Sumberdaya Lahan Sawah dan Bukan Sawah Di DIY, Tahun 2002 sampai dengan 2006.

\begin{tabular}{cccc}
\hline Tahun & $\begin{array}{c}\text { Sawah } \\
\text { (ha) }\end{array}$ & $\begin{array}{c}\text { Bukan sawah } \\
\text { (ha) }\end{array}$ & $\begin{array}{c}\text { Total } \\
\text { (ha) }\end{array}$ \\
\hline 2002 & 58.367 & 260.213 & 318.580 \\
2003 & 58.210 & 260.370 & 318.580 \\
2004 & 57.950 & 260.630 & 318.580 \\
2005 & 57.762 & 260.818 & 318.580 \\
2006 & 57.661 & 260.919 & 318.580 \\
\hline
\end{tabular}

Sumber : Dinas Pertanian DIY, 2007.

Data dalam Tabel 1. menunjukkan bahwa luas lahan sawah selalu menurun dari tahun 2002 sampai dengan 2006. Hal ini menunjukkan bahwa terjadi pengurangan lahan subur akibat konversi atau alih fungsi lahan ke penggunaan diluar pertanian. Luas pengurangan lahan sawah dari tahun 2002 sampai dengan 2006 dapat dilihat pada Tabel 2.

Tabel 2. Luas Pengurangan/ Alih Fungsi Lahan Sawah Di DIY, Tahun 2002 sampai dengan 2006

\begin{tabular}{ccc}
\hline Tahun & $\begin{array}{c}\text { Pengurangan/alih } \\
\text { fungsi lahan (ha) }\end{array}$ & $\begin{array}{c}\text { Persentase } \\
(\%)\end{array}$ \\
\hline 2002 & -181 & 0,31 \\
2003 & -157 & 0,27 \\
2004 & -160 & 0,27 \\
2005 & -288 & 0,50 \\
2006 & -101 & 0,17 \\
\hline Jumlah & -887 & 1,52 \\
\hline Rata-rata & $-177,40$ & 0,30 \\
\hline
\end{tabular}

Sumber : Dinas Pertanian DIY, 2007.

Data dalam Tabel 2. menunjukkan rata-rata terjadi pengurangan lahan sawah sebesar 177,40 hektar atau sebesar 0,30 persen dari keseluruhan luas sawah di DIY. Pengurangan lahan sawah akibat konversi atau alih fungsi lahan perlu dikendalikan agar tidak berlanjut, sehingga diperlukan political will dari pemerintah daerah yaitu pemerintah 
Kabupaten/Kota yang memberikan ketentuan ijin penggunaan lahan, diantaranya dengan instrumen yuridis berupa peraturan yang mengikat dengan sangsi yang sesuai dan memberikan insentif dan disinsentif bagi pemilik lahan.

Data dalam Tabel 1. untuk luas lahan bukan sawah terus meningkat dari tahun 2002 sampai dengan 2006. Peningkatan luas lahan bukan sawah dan penggunaannya dalam pertanian memberikan dukungan untuk tercapainya penyediaan pangan, walaupun tingkat produktifitas dan frekuensi tanam lebih rendah dibandingkan lahan sawah.

2. Ketersediaan dan Potensi Sumberdaya Lahan Pasir Pantai

Ketersediaan sumberdaya lahan pasir pantai selatan DIY sebesar 16.000 hektar, dapat dimanfaatkan untuk mendukung ketahanan pangan, dengan pengelolaan teknologi yang tepat. Bila potensi sumberdaya lahan pasir pantai yang dikelola diasumsikan sebesar 30 persen saja dari keseluruhan luas yang ada, dengan produktifitas lahan sebesar 2 ton per hektar maka diperoleh tambahan produksi beras per tahun sebesar 2.400 ton. Sudah dapat mencukupi penyediaan pangan bagi penduduk sebesar 240.000 jiwa dalam satu tahun dengan pendekatan konsumsi beras per kapita sebesar $100 \mathrm{~kg} /$ tahun.

\section{Kebutuhan Lahan Untuk Penyediaan Pangan}

Total luas lahan sawah di DIY tahun 2006 sebesar 57.661 hektar dengan indek pertanaman padi 150 persen $(1,5 \mathrm{x} /$ tahun $)$, masih ada peluang untuk ditingkatkan menjadi 200 persen $(2 x /$ tahun $)$. Total luas lahan tegalan 260.919 hektar dengan indek pertanaman 80 persen $(0,8 \times /$ tahun $)$, masih ada peluang ditingkatkan menjadi 100 persen. Produksi padi berasal dari 73,49 persen dari lahan sawah dan sebesar 26,51 persen berasal dari lahan bukan sawah yaitu tegalan. Produksi masih dapat ditingkatkan melalui intensifikasi dengan penerapan teknologi dan penggunaan varietas unggul, pemupukan organik dan kimia, budidaya, serta pengendalian kehilangan hasil.

Jumlah penduduk bertambah 0,89 persen/tahun atau sebesar 27.748 jiwa/tahun membutuhkan tambahan produksi padi sebanyak 2.359 ton/tahun gabah kering giling atau setara dengan $1.486,17$ ton beras, berarti memerlukan tambahan luas panen sebesar 413,86 hektar/tahun. Luas panen tersebut memerlukan lahan sebesar 413,86 hektar bila hanya ditanami padi $1 \mathrm{x} /$ tahun atau seluas 206,93 hektar per tahun bila ditanami padi $2 \mathrm{x} /$ tahun. Bila pertambahan penduduk dan alih fungsi lahan sawah tidak dapat dikendalikan maka setiap tahun akan terjadi kehilangan produksi sebesar 3.520 ton/tahun gabah kering giling atau sebesar $2.217,60$ ton/tahun untuk beras.

Agar lebih jelas disajikan komparasi antara produksi dengan konsumsi beras dari tahun ke tahun di D I Y, dalam bentuk grafik sehingga diperoleh kapan kebutuhan beras sudah tidak mencukupi lagi untuk konsumsi penduduk di DIY, dengan perhitungan pertambahan penduduk sebesar 0,89 persen per tahun dan besarnya konsumsi beras 100 $\mathrm{kg} / \mathrm{kapita} /$ tahun.

\section{Peluang Peningkatan Ketahanan Pangan}

Skenario 1 : Intensifikasi, peluang peningkatan produksi melalui peningkatan indeks pertanaman di lahan sawah dari IP 150 persen ke 200 persen dan lahan tegalan 80 persen ke 100 persen. Diikuti dengan penerapan teknologi, penggunaan varietas unggul, pemupukan organik dan kimia, budidaya serta pengendalian kehilangan produksi.

Skenario 2 : Ekstensifikasi, peluang peningkatan produksi melalui perluasan lahan pasir pantai masih terbuka luas.Bila 30 persen saja dikelola dari seluas 16.000 hektar untuk tanaman padi, dengan satu kali tanam dan produktifitas lahan 2 ton beras per hektar maka diperoleh 2.400 ton beras per tahun. 


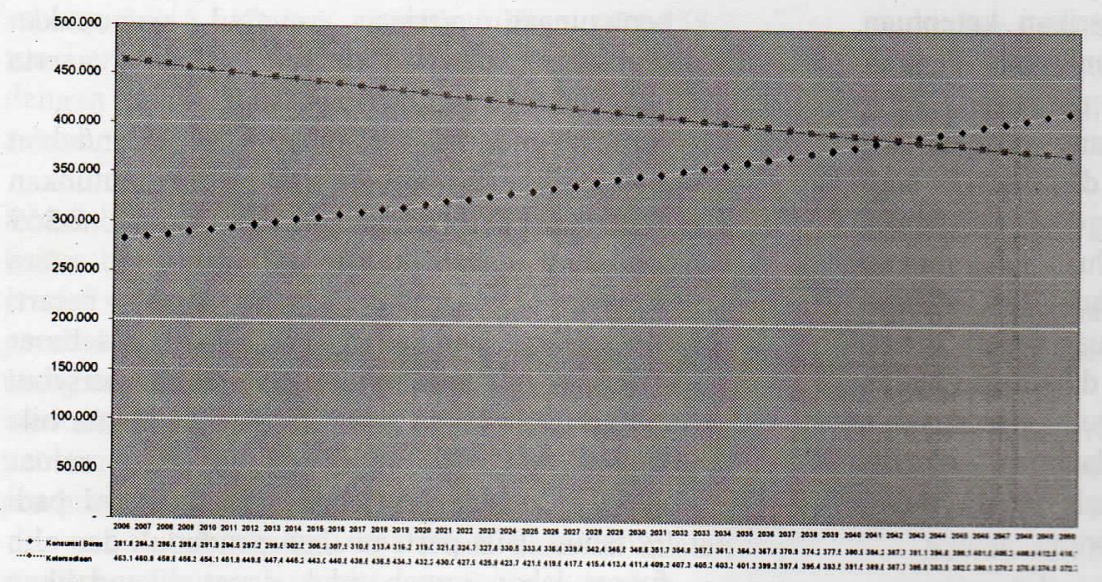

Gambar 1.Komparasi Antara Produksi Dan Konsumsi Beras di DIY

Pada Gambar 1 dapat diketahui bahwa pada tahun 2044 mulai minus pangan karena antara produksi beras sudah tidak dapat mencukupi konsumsi beras penduduk di DIY.

\section{KESIMPULAN DAN IMPLIKASI KEBIJAKAN}

\section{Kesimpulan}

1. Rata-rata terjadi pengurangan lahan sawah sebesar $-177,40$ hektar atau sebesar 0,30 persen per tahun dari keseluruhan luas sawah di DIY

2. Peluang peningkatan ketahanan pangan dapat dilakukan melalui intensifikasi dan ekstensifikasi.

3. Teridentifikasi bahwa pada tahun 2044 mulai tidak tercukupi pangan karena antara produksi beras sudah tidak dapat memenuhi konsumsi beras penduduk di DIY.

\section{Implikasi Kebijakan}

1. Perlu upaya pengendalian konversi lahan sawah,antara lain melalui Peraturan Perundangan dengan sangsi yang sesuai. Disintensif dapat berupa pengenaan pajak tinggi bagi konversi lahan sawah subur di DIY.

2. Indeks pertanaman (IP) ditingkatkan untuk menambah produksi padi di lahan sawah dari 150 persen ke 200 persen dan lahan tegalan dari 80 persen ke 100 persen,dapat menunjang ketahanan pangan di DIY. Untuk pencapaiannya perlu didukung dan diterapkannya kebijakan yang mendorong petani bergairah menanam padi misalnya dengan kebijakan harga pada saat panen raya sehingga ada kepastian harga jual.

3. Pemanfaatan lahan pasir pantai sebesar 30 persen dengan tanaman padi dapat meningkatkan 2.400 ton beras per tahun dan menunjang ketahanan pangan. Perlu kebijakan teknologi sehingga petani pada lahan pasir pantai terdorong untuk memproduksi padi.

\section{DAFTAR PUSTAKA}

BAPEDA, 2007. Data Alih Fungsi Lahan Di DIY. BAPEDA Provinsi DIY. Yogyakarta

Bayudono, 2007. Rencana Pengendalian Tata Ruang Wilayah Dalam Penyediaan Lahan. Dinas KIMPRASWIL Provinsi DIY.Yogyakarta.

Dinas Pertanian ,2007. Kebutuhan lahan dan Penyediaan Pangan Di DIY. Workshop Pemutahiran Data Alih Fungsi Lahan.10-12 Juli 2007.

Suparmoko,2000. Ekonomi Sumberdaya Alam dan Lingkungan. BPFE. Yogyakarta.

Suryana, A.2004. Ketahanan Pangan Di Indonesia. Widyakarya Nasional PANGAN Dan GIZI VIII. 17-19 Mei 2004. Jakarta. 